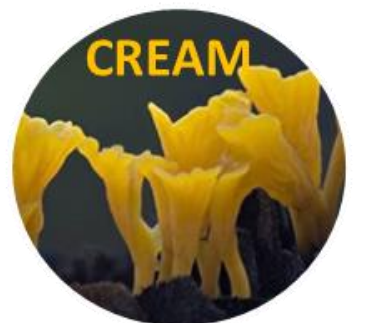

Current Research in Environmental \& Applied Mycology 6 (3): 231-237(2016) ISSN 2229-2225

www.creamjournal.org

Article

CREAM

Copyright (C) 2016

Doi 10.5943/cream/6/3/11

\title{
A new species of Bipolaris from Heliconia rostrata in India
}

\section{Singh $\mathbf{R}^{1}$ and Kumar $\mathbf{S}^{2}$}

\author{
${ }^{1}$ Centre of Advanced Study in Botany, Banaras Hindu University, Varanasi - 221005, Uttar Pradesh, India \\ ${ }^{2}$ Department of Forest Pathology, Kerala Forest Research Institute, Peechi- 680653, Kerala, India
}

Singh R, Kumar S 2016 - A new species of Bipolaris from Heliconia rostrata in India. Current Research in Environmental \& Applied Mycology 6(3), 231-237, Doi 10.5943/cream/6/3/11

\begin{abstract}
Bipolaris rostratae, a new foliicolous anamorphic fungus discovered on living leaves of Heliconia rostrata (Heliconiaceae), is described and illustrated. The species was compared with closely related species of Bipolaris and similar fungi recorded on Heliconia spp. This species is different from other Bipolaris spp. reported on Heliconia due to its shorter, thinner and less septate conidia. A key is provided to all species of Bipolaris reported on Heliconia.
\end{abstract}

Key words - fungal diversity - morphotaxonomy - Foliicolous fungi - Bipolaris - new species

\section{Introduction}

After several taxonomic refinements, graminicolous Helminthosporium were segregated into several genera including Bipolaris, Curvularia, Drechslera and Exserohilum (Sivanesan 1987). These genera belong to Ascomycota, Dothideomycetes, Pleosporales, Pleosporaceae. These genera can be distinguished on the basis of characters such as conidial shape and size, hilum morphology, origin of the germ tubes from the basal or other conidial cells, and the location and sequence in the development of the conidial septa. Illustrations of different hilum morphologies in graminicolous Helminthosporium species were given by Alcorn (1988). The anamorphic genus Drechslera (Pleosporaceae) was described by Ito (1930), which accommodated previously in subgenus Cylindro-Helminthosporium, of graminicolous Helminthosporium. These fungi cause disease on many plant hosts (Zhang \& Berbee 2001) where they are commonly observed in their asexual state (Zhang \& Berbee 2001). Drechslera can be differentiated from all other graminicolous helminthosporoid genera by its ability to develop a germ tube from any of the cells in the conidia (Sivanesan 1987, Alcorn 1988). In Bipolaris conidia germinate by germ tubes from one or both of the end cells. Hilum morphology can also be used to differentiate Bipolaris and Drechslera. In Drechslera a flat scar without protruding hila exists within the lowest part of the basal cell, whereas in Bipolaris it is inconspicuous or very slightly protuberant and is continuous with the conidial wall (Alcorn 1988). Both genera can also be separated on the basis of their sexual morphs; Drechslera has been linked to Pyrenophora sexual morphs, whereas the sexual morph of Bipolaris was Cochliobolus (Drechsler 1934, Alcorn 1983). On molecular phylogenetic analyses it has been proved that Drechslera and Bipolaris are two distinct genera (Berbee et al. 2000).

Another fungus, Exserohilum Leonard \& Suggs (1974), can be differentiated from other graminicolous helminthosporoid genera by a truncate, strongly protruding hilum with redudant bases, often with an enveloping bubble. The conidia germinate by germ tubes originating from either one or 
both of the end cells or other intermediate cells. The sexual morphs of Exserohilum have been placed in Setosphaeria (Leonard \& Suggs 1974).

Bipolaris Shoemaker (1959) and Curvularia Boedijn (1933) share many morphological similarities (Sivanesan 1987) and both genera have sexual morphs in Cochliobolus (Drechsler, 1934). Phylogenetic relationships based of sequences from four gene regions (ITS, GPDH, LSU and EF1- $\alpha$ ) from ex-type strains of Bipolaris, Cochliobolus and Curvularia spp. prove that Bipolaris and Curvularia are two monophyletic groups which indicate separate generic status (Manamgoda et al. 2012) and these findings are in agreement with previous studies (Shimizu et al. 1998, Berbee et al. 1999, Kodsueb et al. 2006). Although the asexual morphs cluster in two well defined groups (Bipolaris and Curvularia) based on molecular data and morphology, their sexual morphs are quite similar indicating that the asexual states have evolved and differentiated more rapidly than the sexual morphs (Manamgoda et al. 2012, 2014). Bipolaris is characterized by large canoe-shaped conidia, and lack stromata, branched to unbranched conidiophores with polytretic conidiogenous cells and pseudoseptate conidia with scar very slightly protuberant which is continuous with the conidial wall. Curvularia species have straight to curved conidia, and usually stromata below the ascomata.

During a regular visit of the Botanical Garden of Deen Dayal Upadhyay Gorakhpur University, Gorakhpur, India, some Heliconia rostrata (Hanging Lobster Claw or False Bird of Paradise) plants showed leaf spot symptoms of various sizes which were caused by a Bipolaris species. Upon a critical morphological examination and comparison of its morphotaxonomic features with those of the currently accepted species of this genus, it was considered to represent a novel taxon.

\section{Materials and Methods}

Specimens of living leaves with disease symptoms suggesting the presence of parasitic fungi, were collected at the Botanical garden of the Deen Dayal Upadhyay (DDU) Gorakhpur University, Gorakhpur in 2012. The collected samples were carried to the laboratory and processed by following standard protocols (Hawskworth, 1974, Savile, 1962). The dried and pressed infected leaf samples were placed inside adsorbant paper envelops along with collection details and than kept in air tight polyethylene bags. Photographs of infection spots on leaf surface were taken by using Sony DSC5730 camera. Free hand cut sectioning and scrappings were made through infection spots mounted in clear lactophenol cotton-blue mixture for the morphological observation of microscopic structures. Observations were made with an Olympus BX-51 light microscope by using Syntek USB camera. Detailed observations of morphological characters and Line drawings were carried out at different magnification through light microscope $(450 \times$ and $1000 \times)$. The measurements of 30 conidia, hila, and conidiophores and conidiogenous cells, with the extremes given in parentheses were done with the help of combination of stage and ocular micrometer. The holotype is deposited in Ajrekar Mycological Herbarium (AMH), Agharkar Research Institute (ARI), Pune, India; and an isotype was retained in the herbarium of the Department of Botany, D.D.U. Gorakhpur University (GPU), Gorakhpur. The systematic position of the taxa is given in accordance with following literatures [Ellis (1971, 1976), Cannon and Kirk (2007), Kirk et al. (2008), Seifert et al. (2011), Farr and Rossman (2015), MycoBank (www.mycobank.org; accessed 30 April 2015) and the Index Fungorum (www.indexfungorum.org; accessed 30 April 2015)].

\section{Results}

\section{Taxonomy}

Bipolaris rostratae Raghv. Singh \& Sham. Kumar, sp. nov.

Figs. 1-3 MycoBank MB 812424

Diagnoses - Differs from other Bipolaris spp. reported on Heliconia due to its shorter, thinner and less septate conidia.

Etymology - the epithet rostratae is derived from name of host species. 

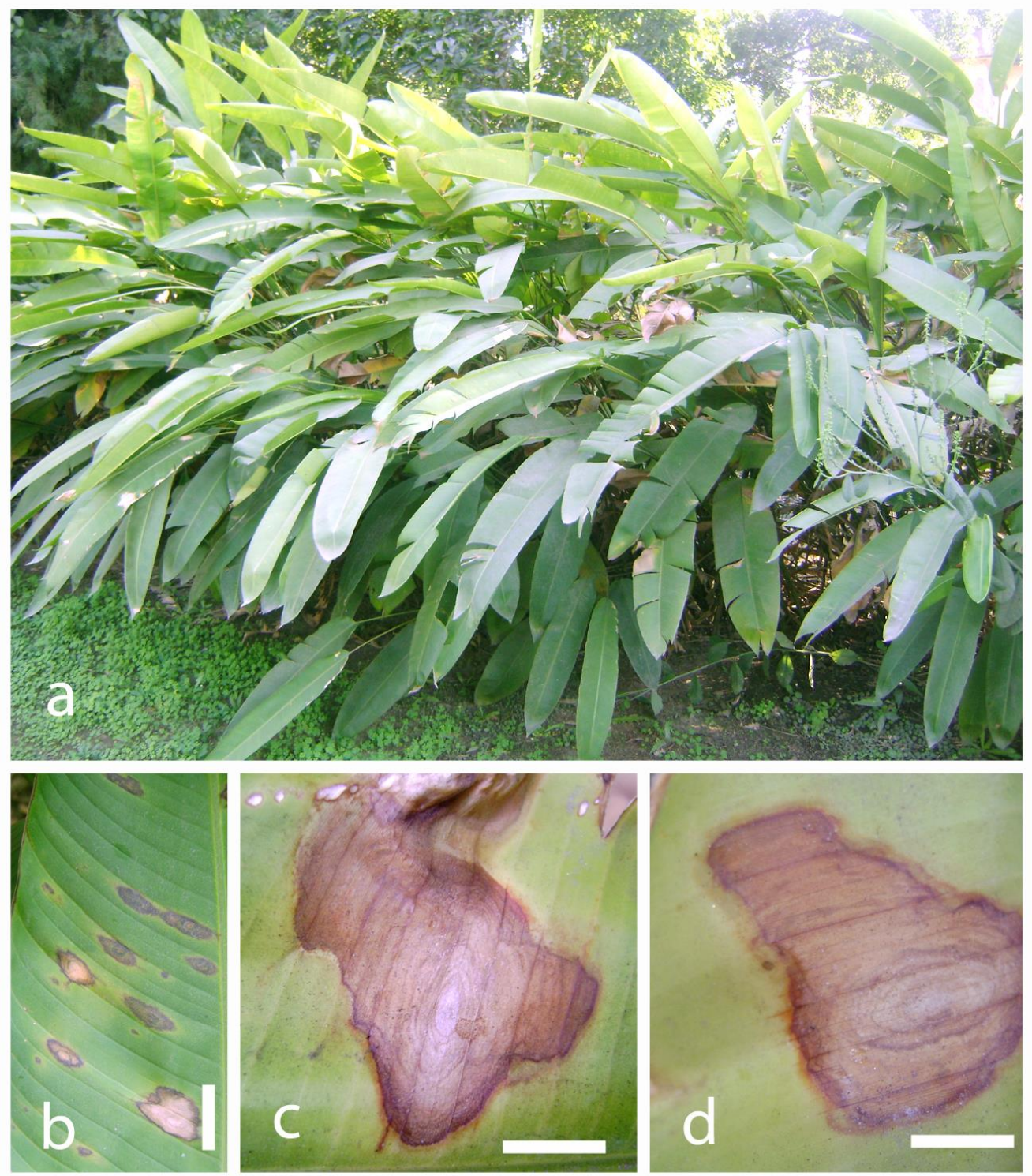

Fig. 1 Heliconia rostrata (AMH 9480, holotype). a. Host plant habit. B. Early stage of infection. c-d. Late stage of infection. Scale bars $\mathbf{b}-\mathbf{d}=20 \mathrm{~mm}$.

Anamorphic fungus, Hyphomycetes, Foliicolous, Parasitic, Infection spots amphigenous, initially circular to subcircular, but later irregular and spread on the entire leaf surface, yellowish brown to dark brown in colour. Colonies epiphyllous, usually effuse, brown. Mycelium internal. Sexual morph: undetermined. Asexual morph: Stromata absent. Conidiophores macronematous, mononematous, branched to unbranched, cylindrical, erect to procumbent, straight to flexuous, geniculate, smooth, thick-walled, 1-8-septate, mid brown to blackish brown, base bulbous, tip normally swollen, $(25-) 30-205(-220) \times(2.5-) 3-6(-8) \mu \mathrm{m}$. Conidiogenous cell integrated, terminal to intercalary, monotretic to polytretic, conidiogenous loci thickened, $1.5-2.5 \mu \mathrm{m}$ wide. Conidia solitary, simple, acropleurogenous, usually cylindrical to obclavate-cylindrical to fusiform or occasionally orbicular, straight to curved, smooth, thick-walled, mid brown to blackish brown, some conidia constricted at septa, base rounded and apex obtuse, $(20-) 22-65(-72) \times(5-) 6-12(-13.5) \mu \mathrm{m}$, 2-8-distoseptate, hila thickened, $1.5-2.5 \mu \mathrm{m}$ wide. Conidia germinating at both ends.

Known distribution - India

Material examined- India, Uttar Pradesh, Gorakhpur, DDU Gorakhpur University, Botanical Garden, on living leaves of Heliconia rostrata Ruiz \& Pav. (Heliconiaceae), 11 February 2012, coll., Raghvendra Singh, AMH 9480 (holotype), GPU 604 (isotype).

Teleomorph - Not seen. 


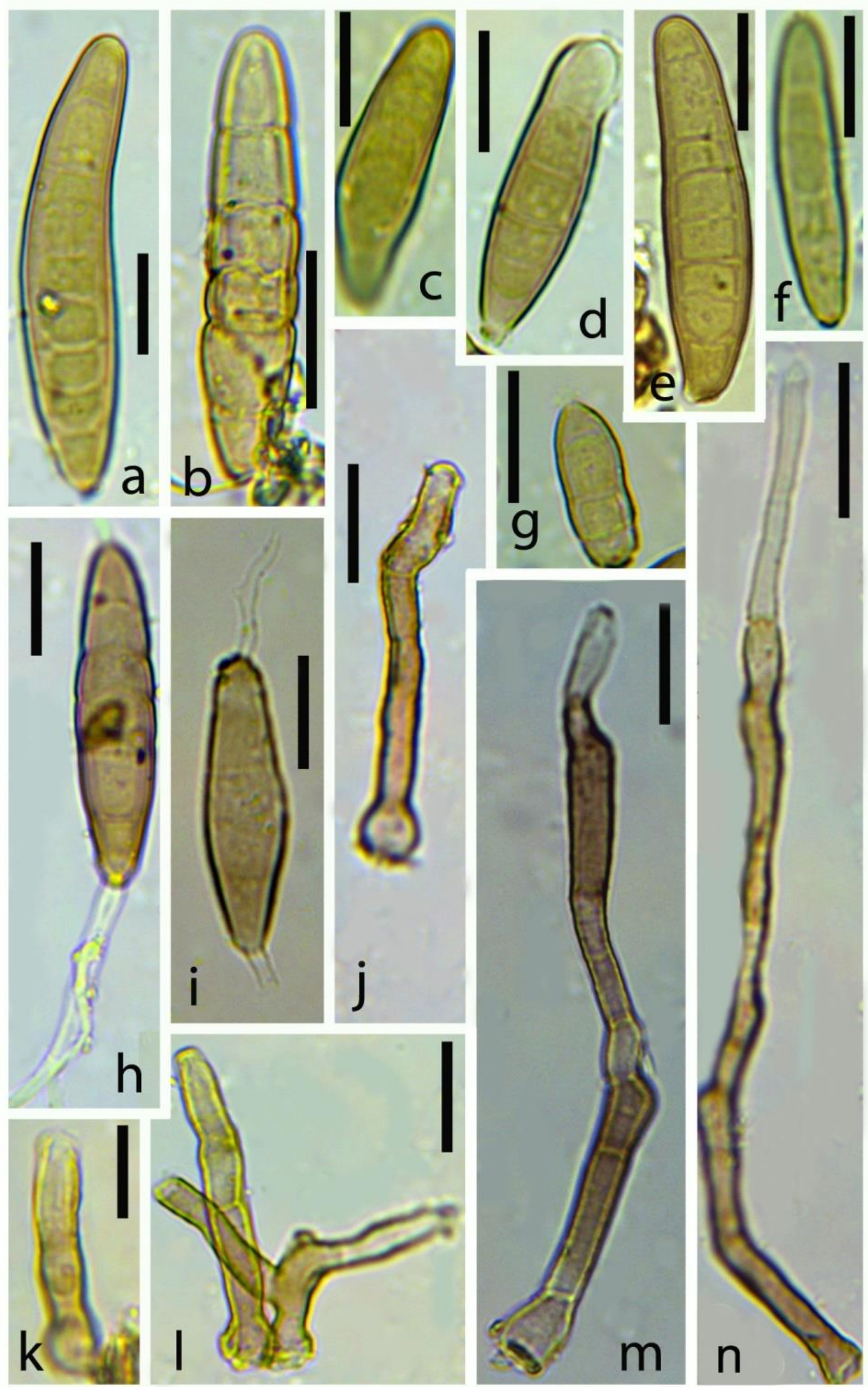

Fig. 2 - Bipolaris rostratae, microphotographs (AMH 9480, holotype). a-g. Conidia. h-i. Germinated conidia at both end. $\mathbf{j}-\mathbf{n}$. Conidiophores. Scale bars $\mathbf{a}-\mathbf{n}=20 \mu \mathrm{m}$ 


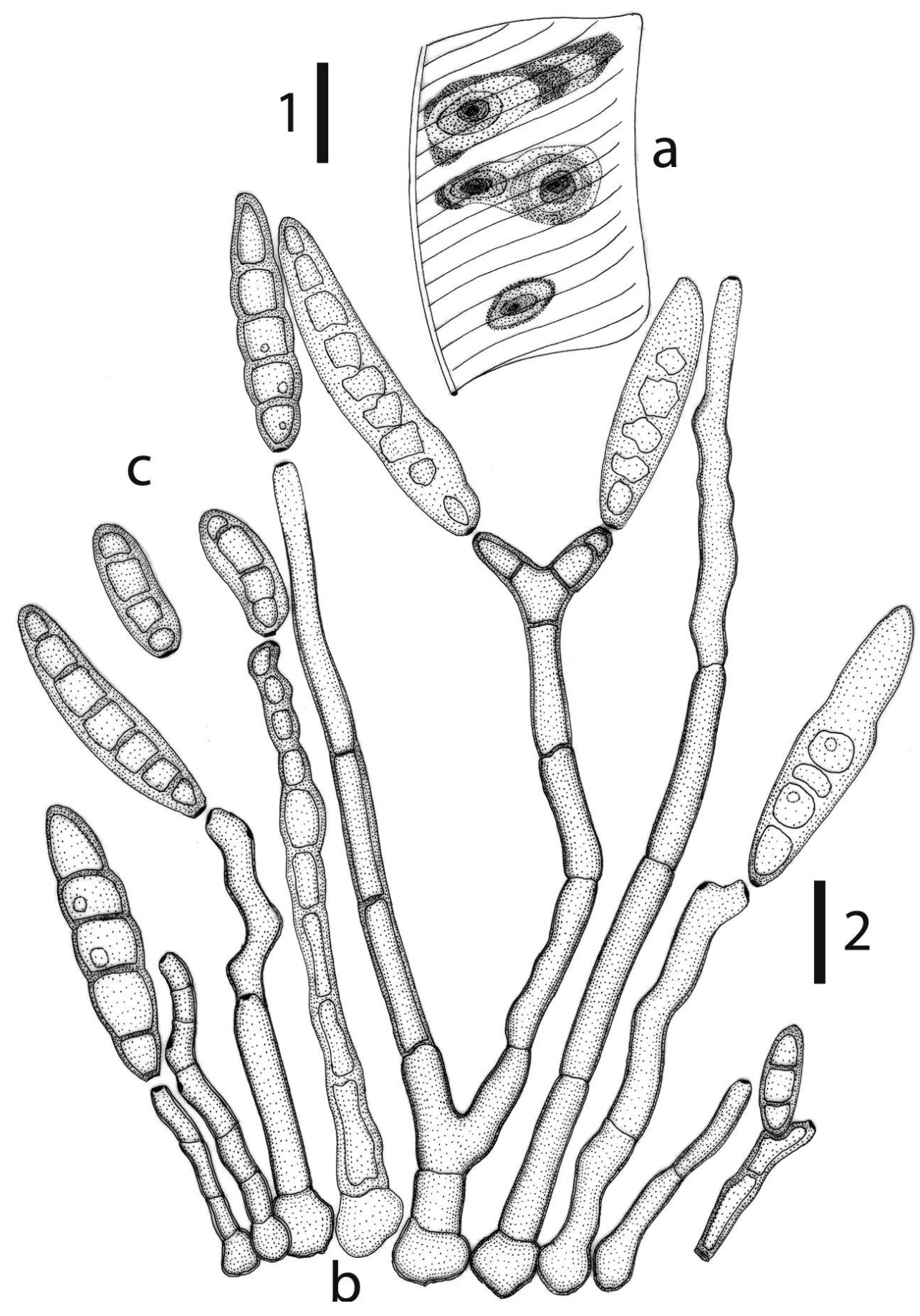

Fig. 3 - Bipolaris rostratae, drawings (AMH 9480, holotype). a. Infection spot. b. Conidiophores. c. Conidia. Scale bars $\mathbf{1}=20 \mathrm{~mm}, \mathbf{2}=20 \mu \mathrm{m}$.

\section{Discussion}

A survey of literature indicated that a number of Bipolaris spp. have been recorded on Heliconia spp. viz., B. cynodontis Shoemaker (1959), B. heliconiae Alcorn (1996), B. incurvata Alcorn (1983a), B. salviniae Alcorn (1991) and B. setariae Shoemaker (1959).

The conidia of Bipolaris rostratae [(20-)22-65(-72) $\times(5-) 6-12(-13.5) \quad \mu \mathrm{m}, \quad 2-8-$ distoseptate] are shorter, thinner and less septate compared to B. cynodontis $[(27-) 40-80(-100) \times$ $(10-) 12-18(-20) \mu \mathrm{m}, \quad(3-) 7(-9)$-distoseptate $], \quad B$. heliconiae $[65-150 \times 15-19 \mu \mathrm{m}, \quad 7-10-$ distoseptate], B. incurvata [100-150 × 19-22 $\mu \mathrm{m}, 8-13$-distoseptate], B. salviniae [(75-)100-170($190) \times(10-) 13-17(-19) \mu \mathrm{m},(6-) 10(-14)$-distoseptate $]$ and B. setariae $[(50-) 65-100(-108) \times(10-$ )13-16 $\mu \mathrm{m},(5-) 8(-10)$-distoseptate]. Thus, the fungus $B$. rostratae is designated as new species. 


\section{Identification key to Bipolaris species on Heliconia spp.}

1 Conidia smooth, shorter, thinner and less septate.

$1 *$ Conidia smooth or slightly verruculose, longer $(>72 \mu \mathrm{m})$, thicker $(>13.5 \mu \mathrm{m})$ and more septate $(>8)$

2 Conidia (20-)22-65(-72) $\times(5-) 6-12(-13.5) \mu \mathrm{m}, 2-8$-distoseptate Bipolaris rostratae

3 Nature of germination in conidia 4

4 End cells sometimes swollen to produce a thin, globose vesicle where germ tubes originate ..............5

4* Germ tubes originating from both or one end cells without forming a vesicle

5 Conidia hyaline when immature, turning olivaceous green, then brown or golden brown when mature, $(27-) 40-80(-100) \times(10-) 12-18(-20) \mu \mathrm{m},(3-) 7(-9)$-distoseptate. B. cynodontis

6. Conidia pale brown, olivaceous brown, golden brown .......................................................... 7

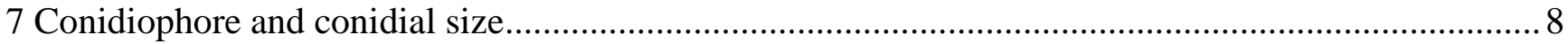

8 Conidia less than $150 \mu \mathrm{m}$ long, conidiophores less than $350 \mu \mathrm{m}$ long......................................... 9

$8^{*}$ Conidia length equal to or more than $150 \mu \mathrm{m}$, Conidiophores more than $350 \mu \mathrm{m}$ long .................. 10

9. Conidia (50-)65-100(-108) $\times(10-) 13-16 \mu \mathrm{m},(5-) 8(-10)$-distoseptate, Conidiophores (96-) 145207(-218) × 4-6 $\mu \mathrm{m}$

B. setariae

10. Conidia less than $20 \mu \mathrm{m}$ wide

$10 *$ Conidia more than $20 \mu \mathrm{m}$ wide

11. Conidia 65-150 × 15-19 $\mu \mathrm{m}, 7-10$-distoseptate

B. heliconiae

$11^{*}$ Conidia (75-)100-170(-190) $\times(10-) 13-17(-19) \mu \mathrm{m},(6-) 10(-14)$-distoseptate.

B. salviniae

12 Conidia $100-150 \times 19-22 \mu \mathrm{m}, 8-13$-distoseptate

B. incurvata

\section{Acknowledgements}

We are thankful to the Head, CAS in Botany, Banaras Hindu University, Varanasi and Director, Kerala Forest Research Institute, Peechi, Kerala for necessary facilities. Thankfulness is also due to both anonymous reviewers for reviewing the manuscript with relevant comments and suggestions. Raghvendra Singh thanks to the University Grant Commission (UGC), Faculty Research Promotion Scheme (FRPS/2014), Govt. of India and Shambhu Kumar extends thanks to the SERB, DST, Govt. of India for financial assistance (SB/YS/LS-288/2013). Authors are indebted to the Curator of AMH, Agharkar Research Institute (ARI), Pune, for accepting the holotype specimens and providing an accession number.

\section{References}

Alcorn JL. 1983 - On the genera Cochliobolus and Pseudocochliobolus. Mycotaxon 16, 353-379.

Alcorn JL. 1988 - The taxonomy of "Helminthosporium" species. Annual Review of Phytopathology 26, 37-56.

Alcorn JL. 1991 - Combinations and synonymy in Bipolaris and Curvularia, and a new species of Exserohilum. Mycotaxon 41(2), 329-343.

Alcorn JL. 1996 - Cochliobolus heliconiae sp. nov. (Ascomycota). Australian Systematic Botany 9(5), 813-817.

Alcorn, JL. 1983a - Generic concepts in Drechslera, Bipolaris and Exserohilum. Mycotaxon 17, 186.

Berbee M, Pirseyedi M, Hubbard S. 1999 - Cochliobolus phylogenetics and the origin of known, highly virulent pathogens, inferred from ITS and glyceraldehyde-3-phosphate dehydrogenase gene sequences. Mycologia 91, 964-977.

Berbee ML, Carmean DA, Winka K. 2000 - Ribosomal DNA and resolution of branching order among the ascomycota: how many nucleotides are enough? Molecular Phylogenetics and Evolution 17, 337-344.

Boedijn, KB. 1933 - Über einige phragmosporen Dematiazen. Bulletin du Jardin Botanique de Buitenzorg 13(1), 120-134. 
Cannon PF, Kirk PM. 2007 - Fungal Families of the World. Wallingford, Oxfordshire, UK: CAB International. pp. 456.

Drechsler C. 1934 - Phytopathological and taxonomical aspects of Ophilobolus, Pyrenophora, Helminthosporium and a new genus Cochliobolus. Phytopathology 24, 953-981.

Ellis MB. 1971 - Dematiaceous Hyphomycetes. Commonwealth Mycological Institute, Kew, England. pp. 608.

Ellis MB. 1976 - More Dematiaceous Hyphomycetes. Commonwealth Mycological Institute, Kew, England. pp. 507.

Farr DF, Rossman AY. 2015 - Fungal Databases, Systematic Mycology and Microbiology Laboratory, ARS, USDA. Retrieved April 30, 2015, from http://nt.arsgrin.gov/fungaldatabases/

Hawskworth DL. 1974 - Mycologist's Handbook. Commonwealth Mycological Institute, Kew. pp. 231.

Index Fungorum 2015 - Index Fungorum. http://www.indexfungorum.org, accessed 30 April 2015.

Ito S. 1930 - On some new ascigerous stages of the species of Helminthosporium parasitic on cereals. Supplement of Proceedings of the Imperial Academy of Japan 6, 352-355.

Kirk PM, Cannon PF, Minter DW, Stalpers JA. 2008 - Dictionary of the Fungi. 10th ed. Wallingford, UK: CAB International. pp. 771.

Kodsueb R, Dhanasekaran V, Aptroot A, Lumyong S, McKenzie EHC, Hyde KD, Jeewon R. 2006 The family Pleosporaceae: intergeneric relationships and phylogenetic perspectives based on sequence analyses of partial 28S rDNA. Mycologia 98, 571-583.

Leonard KJ, Suggs EG. 1974 - Setosphaeria prolata, the ascigerous state of Exserohilum prolatum. Mycologia 66, 197-281.

Manamgoda DS, Cai L, McKenzie EHC, Crous PW, Madrid H, Chukeatirote E, Shivas RG, Tan YP, Hyde KD. 2012 - A phylogenetic and taxonomic re-evaluation of the Bipolaris Cochliobolus - Curvularia complex. Fungal Diversity 56, 131-144. http://dx.doi.org/10.1007/s13225-012-0189-2

Manamgoda DS, Rossman AY, Castlebury LA, Crous PW, Madrid H, Chukeatirote E, Hyde KD. 2014 - Studies in Mycology 79, 221-288.

MycoBank 2015 - MycoBank (Fungal databases nomenclature and species banks). www.mycobank.org, accessed 30 April 2015.

Savile DBO. 1962 - Collection and care of Botanical specimens. Canadian Department of Agriculture, Publication, Research Branch 1113, 1-124.

Seifert KA, Morgan-Jones G, Gams W, Kendrick WB. 2011 - The Genera of Hyphomycetes. CBSKNAW Fungal Biodiversity Centre, Utrecht, The Netherland. CBS Biodiversity Series no. 9, 997.

Shimizu K, Tanaka C, Peng YL, Tsuda M. 1998 - Phylogeny of Bipolaris inferred from nucleotide sequences of Brn1, a reductase gene involved in melanin biosynthesis. J. Gen. Appl. Microbiol. 44, 251-258.

Shoemaker RA. 1959 - Nomenclature of Drechslera and Bipolaris, grass parasites segregated from 'Helminosporium'. Canadian Journal of Botany 37(5), 879-887.

Sivanesan A. 1987 - Graminicolous species of Bipolaris, Curvularia, Drechslera, Exserohilum and their teleomorphs. CAB International. pp. 261.

Zhang G, Berbee ML. 2001 - Pyrenophora phylogenetics inferred from ITS and glyceraldehyde-3phosphate dehydrogenase gene sequences. Mycologia 93, 1048-1063. 